JURNAL PENDIDIKAN, p-ISSN 2715-095X, e-ISSN 2686-5041

Volume 30, No.2, Juli 2021 (261-272)

Online: http://journal.univetbantara.ac.id/index.php/jp

\title{
Peningkatan Hasil Belajar IPA Materi Konduktor dan Isolator Metode Discovery Learning Siswa Kelas VI SDN Cemani 03 Tahun Pelajaran 2018/2019
}

\section{Hariyono}

SDN Cemani 03, Grogol Sukoharjo, Kabupaten Sukoharjo, E-mail: hariyonospd9@gmail.com

Received: Mey 27, 2021

Accepted: Juni 2, 2021

Online Published: Juni 26, 2021

\begin{abstract}
Abstrak: Latar belakang dari penelitian tindakan kelas ini adalah hasil belajar siswa sangat memprihatinkan karena dari 37 siswa kelas VI hanya 23 siswa yang mencapai tingkat penguasaan materi $62 \%$ keatas. Rumusan masalah dalam penelitian ini adalah apakah pembelajaran dengan menggunakan discovery learning dapat meningkatkan hasil belajar IPA materi kondutor dan isolator siswa kelas VI SDN Cemani 03 Kabupaten Sukoharjo Semester 2 tahun pelajaran 2018/2019. Waktu penelitian selama 5 bulan mulai bulan Januari 2019 sampai Mei 2019. Kegiatan tersebut dibagi dalam tahapan yaitu tahap ijin penelitian, tahap pelaksanaan dan tahap penyusunan laporan hasil penelitian. Subjek penelitian adalah seluruh siswa kelas VI Sekolah SDN Cemani 03 Kabupaten Sukoharjo Semester 2 Tahun Pelajaran 2018/2019 yangberjumlah 37 siswa Objek penelitian ini adalah proses pembelajaran untuk meningkatkan Hasil Belajar IPA Materi Konduktor dan Isolator pada siswa kelas VI SDN Cemani 03 Kabupaten Sukoharjo melalui penggunaan metode pembelajaran discovery learning. Penelitian Tindakan Kelas ini, menggunakan tiga pengumpulan data yaitu observasi, dokumentasi dan tes. Hasil penelitian menunjukkan bahwa "Melalui pembelajaran discovery learning di duga dapat meningkatkan hasil belajar IPA siswa materi konduktor dan isolator siswa kelas VI SDN Cemani 03 Kabupaten Sukoharjo semester 2 tahun pelajaran 2018/2019" terbukti kebenarannya" Peningkatan nilai rata-rata hasil belajar siswa, yaitu dari 68 pada kondisi awal meningkat menjadi 79 pada Siklus I dan meningkat kembali menjadi 85 pada siklus II. Sedangkan peningkatan ketuntasan belajar siswadari $62 \%$ pada kondisi awal meningkat menjadi $81 \%$ pada siklus I dan meningkat menjadi $100 \%$ pada siklus II.
\end{abstract}

Kata-kata Kunci:: discovery learning, hasil belajar,IPA

\section{Improvement Science Learning Outcomes for Conductors And Isolators In The Discovery Learning Method for Class VI Students of SDN Cemani 03 Academic Year 2018/2019}

\section{Hariyono}

SDN Cemani 03, Grogol Sukoharjo, Sukoharjo Regency, email:hariyonospd9@gmail.com

\begin{abstract}
The background of this classroom action research is that student learning outcomes are very apprehensive because of the 37 grade VI students only 23 students reached the level of mastery of the material above 62\%. The formulation of the problem in this study is whether learning using discovery learning can improve science learning outcomes of the conductor and isolator material for class VI SDN Cemani 03 Sukoharjo Regency Semester 2 in the 2018/2019academic year. The research period was 5 months from January 2019 to May 2019.
\end{abstract}


The activity was divided into stages, namely the research permit stage, the implementation stage and the research report preparation stage. The research subjects were all grade VI students of SDN Cemani 03, Sukoharjo District, Semester 2, 2018/2019 academic year, totaling 37 students. through the use of discovery learning methods. This Classroom Action Research uses three data collections, namely observation, documentation and tests. The results showed that "Discovery learning can improve students' science learning outcomes in the material of conductors and isolators for class VI SDN Cemani 03 Sukoharjo Regency in the second semester of the 2018/2019 academic year" proved to be true "Increasing the average value of student learning outcomes, that is, from 68 in the initial conditions it increases to 79 in the first cycle and increases again to 85 in the second cycle. While the increase in student learning completeness from $62 \%$ in the initial conditions increased to $81 \%$ in cycle I and increased to $100 \%$ in cycle II.

Keywords: discovery learning, learning outcomes, science

\section{Pendahuluan}

Materi IPA di Sekolah Dasar kelas VI salah satunya memuat tentang konduktor dan isolator, materi pelajaran ini mengharapkan siswa untuk mampu membandingkan sifat sifat benda yang dapat menghantarkan panas dengan baik. sehingga diperoleh pengalaman belajar yang diharapkan yaitu siswa dapat membedakan benda yang dapat menghantarkan panas dan tidak dapat menghantarkan panas selain itu siswa juga dapat menjelaskan alasan pemilihan benda dalam kehidupan sehari-hari berdasarkan kemampuan menghantarkan panas. Dalam mengajarkan materi IPA di SD Negeri Cemani 03 Kabupaten Sukoharjo, guru mencoba mengajarkan materi pembejaran melalui metode ceramah dengan cara siswa diminta mencatat seluruh materi yang dijelaskan oleh guru. Menurut pengamatan peneliti, selama proses pembelajaran berlangsung sebagian besar siswa sangat memperhatikan penjelasan guru bahkan catatan siswa juga cukup lengkap. Tetapi hal ini tidak sesuai yang diharapkan oleh guru karena hasil yang diperoleh siswa sangat memprihatinkan karena dari 37 siswa kelas VI hanya 23 (dua puluh tiga) siswa yang mencapai tingkat penguasaan materi $62 \%$ keatas.

Salah satu usaha yang dilakukan siswa adalah membuat catatan. Mereka mencatat materi pelajaran akan tetapi, mereka tidak dapat menyerap materi dengan baik (Suwarto, 2009). Dengan metode pembelajaran alternatif yang tepat dirasa dapat membantu pemecahan permasalahan tersebut. Guru harus mampu dan kreatif untuk memvariasi metode pembelajaran sehingga diharapkan mampu meningkatkan hasil belajar semaksimal mungkin. Peneliti mengamati dari data nilai harian kelas VI semester 2 didapat nilai ratarata 68 , terlihat jelas bahwa nilai rata-rata siswa masih kurang memuaskan dan juga masih belum memenuhi nilai ketuntasan belajar yang ditetapkan yaitu 70. Rendahnya nilai ratarata kelas disebabkan oleh siswa kurang antusias mengikuti pelajaran IPA dikarenakan kurang tepatnya metode, model ataupun strategi yang digunakan guru dalam mengajar IPA (Suprapti Hariyani, 2019). Oleh sebab itu peneliti mencoba alternative pembelajaran menggunakan metode Discovery Learning. Pembelajaran ini didominasi oleh siswa, sehingga siswa lebih kreatif dan juga berani untuk mengemukakan keberaniannya. Pasal 1 
Undang-undang No. 20 tahun 2003 tentang Sistem Pendidikan Nasional menyebutkan bahwa pembelajaran merupakan suatu hubungan timbal balik yang saling berhubungan erat antara siswa, guru dan sumber belajar di suatu lingkungan belajarnya. Secara garis besar pembelajaran bisa dikatakan sebuah proses yang disengaja untuk mencapai suatu hal, antara lain perubahan tingkah laku, bertambahnya keahlian dan meningkatkan mutu seseorang.Menurut Hilgrad dan Bower, 1966 dalam (Jogiyanto, 2006:10) proses pembelajaran hendaknya berpusat pada hal hal antara lain yaitu untuk meningkatkan mutu berpikir yaitu meningkatkan kualitas atau mutu berpikir agar lebih efisien, sehingga siswa mampu konstruktif, dan keaktifan. Meningkatkan attitude of mind, yaitu memfokuskan pada rasa ingin tahu yang mengaspirasi pada penemuan penemuan yang bermanfaat. Meningkatkan karakter yang bertanggunjawab, peka dan berintegritas sehingga menciptakan kualitas mutu personal yang berkarakter. Meningkatkan kemampuan mengembangkan konsep, wawasan pengetahaun yang dapat digunakan dalam situasi tertentu. Belajar merupakan proses manusia untuk mencapai berbagai macam kompetensi, keterampilan dan sikap. Belajar dimulai sejak manusia lahir sampai akhir hayat, Karakteristik manusia yang membedakan manusia dengan makhluk lainnya adalah kemampuan manusia untuk belajar. Dalam kamus besar Bahasa Indonesia seperti yang dikutip Baharudin dan Wahyuni (2007: 13), belajar memiliki arti "berusaha mencari kepandaian atau ilmu". Untuk memperoleh kepandaian diperlukan usaha atau ilmu, usaha atau ilmu disini diperoleh agar manusia dapat memenuhi kebutuhannya, kebutuhan akan mendapat ilmu atau kepandaian yang belum dicapai sebelumnya, dengan belajar manusia menjadi lebih mengetahui, lebih memahami, dan akan lebih mengerti, dalam melakukan sesuatu. Perilaku tersebut dapat berupa cakupan pengetahuan, pemahaman, keterampilan, sikap, dal lain-lain. Kecenderungan perilaku seseorang dapat diidentifikasi dengan pengetahuan, pemahaman, keterampilan, sikap, dan sebagainya yang dimiliki seseorang selain itu perilaku seseorang bisa diukur ataupun dilihat dari penampilan, kemampuan tersebut meliputi kemampuan melakukan tindakan, kemampuan menjelaskan sesuatu yang lebih spesifik, dan kemampuan mengutarakan suatu hal.

Berdasarkan pandangan-pandangan belajar penulis menyimpulkan bahwa pengertian belajar adalah suatu kegiatan proses interaksi dalam rangka usaha untuk mengadakan perubahan sifat ataupun tingkah laku seseorang, baik berupa pengetahuan kebiasaan ataupun sikap yang diperoleh dari hasil pengalaman dan latihan. Keadaan seseirang yang telah belajar akan berbeda dengan keadaan seseoarng yang belum belajar. Setelah belajar akan terjadi perubahan tingkah laku dari orang tersebut yang dapat dilihat dari perbuatannya. Seseorang yang telah mengalami perubahan tingkah laku dan perubahan tersebut diterapkan dalam perbuatan dan menjadikannya suatu pengalaman bisa dikatakan orang tersebut telah belajar. Berdasarkan definisi tentang belajar yang diungkapkan para ahli, dapat disimpulkan ciri belajar antara lain, seperti yang disampaikan Baharudin dan Wahyuni (2007: 15-16) Adanya perubahan tingkah laku (change behavior) merupakan salah satu ciri belajar. Hasil dari belajar dapat diamati dari tingkah laku perbuatan dari tidak mengerti atau tidak tahu menjadi mengerti, memahami, tidak terampil menjadi terampil; Perubahan perilaku relative permanent, perubahan belajar yang terjadi dalam kurun waktu tertentu, akan tetap terus digunakan atau tidak akan berubah-ubah, akan tetapi perubahan tersebut tidak akan terpancang seumur hidup; Pada saat proses kegiatan pembelajaran berlangsung proses perubahan tingkah laku tidak hatrus segera diamati perubahan perilaku tersebut bersifat potensial; Pengalaman diperoleh dari perubahan sebuah latihan dari perubahan tingkah laku; Penguatan diperoleh dari sebuah latihan ataupun pengalaman. 
Dengan semangat dan dorongan diharapkan dapat memperkuat seseorang untuk mengubah tingkah. Beberapa faktor tersebut dikelompokkan sebagai berikut (Baharudin dan Wahyuni, 2007: 19-28):Faktor internal atau dari dalam peserta didik, yaitu faktor-faktor yang berasal dari dalam individu dan dapat mempengaruhi hasil belajar individu. Faktor dari dalam peserta didik ini terdiri dua macam yaitu faktor fisiologi dan psikologi. Faktor fisiologi, merupakan faktor yang berkaitan dengan kondisi fisik seseorang, yang meliputi keadaan badan atau fisik dan fungsi badan/fisik seseorang. Faktor psikologi, Keadaan seseorang yang sangat berpengaruh dalam proses belajar dari segi kejiwaan seseorang. Beberapa faktor psikologis yang utama mempengaruhi proses belajar adalah kecerdasan (intelegensia) siswa, motivasi, minat, sikap dan bakat, Faktor dari luar atau eksternal, yaitu faktor-faktor yang berasal dari luar diri siswa yang dapat mempengaruhi proses belajar. Faktor dari luar ini dibedakan menjadi dua, yaitu faktor dari lingkungan sosial dan faktor dari lingkungan nonsosialnya.Lingkungan sosial, meliputi lingkungan: (1) sekolah, yaitu guru, administrasi, dan teman sekelas; (2) sosial masyarakat, yaitu tempat tinggal dimana lingkungan siswa tersebut berada; (3) sosial keluarga yaitu unsur dari keluarga meliputi hubungan dengan orangtuanya, hubugan dengan saudaranya, hubungan dengan anggota keluarga lainnya, hubungan antar anggota keluarga lain sebagainya.

Lingkungan non sosial meliputi: (1) lingkungan alami, misalnya suasana alam dan kondisi alam di sekitar siswa; dan (2) faktor instrumental, yang meliputi: (i) hardware seperti tempat belajar, peralatan belajar, sarana prasarana belajar lainnya; (ii) software, contohnya pedoman kurikulum yang digunakan di sekolah, peraturan sekolah, dan silabus pembelajaran; (3) faktor dari materi mata pelajaran yang akan diberikan dan metode mengajar guru hendaknya tepat sesuai dengan perkembangan siswa. Dari uraian-uraian di atas, belajar yang terjadi dalam diri seseorang terjadi dalam rangka menuju perubahan ke tingkat yang lebih baik lagi bersama dengan faktor-faktor di dalamnya. Belajar pada hakekatnya adalah sebuah hubungan timbal balik yang saling berkaitan antara individu dengan lingkungan sekitarnya, karena belajar tidak semata-mata sebagai upaya dalam merespon stimulus, tetapi lebih dari itu belajar dilakukan melalui berbagai kegiatan seperti mengalami, mengerjakan, sehingga dieproleh perubahan tingkah laku yang konsisten sepanjang waktu. Dalam melakukan proses belajar digunakan seluruh kemampuan dasar yang dimilikinya sebagai dasar untuk melakukan berbagai kegiatan agar diperoleh hasil belajar. Menurut Gagne dalam Dimyati dan Mudjiono (2006: 11-12) belajar merupakan interaksi antara "keadaan internal dan proses kognitif siswa" dengan stimulus dari lingkungan". Proses kognitif tersebut menghasilkan suatu hasil belajar. Perolehan hasil belajar dari proses belajar beraneka ragam, dari yang sederhana sampai yang paling kompleks, yaitu berupa kapabilitas yang diperoleh atau didapat dari informasi verbal, keterampilan intelektual, keterampilan motorik, sifat, dan siasat kognitif. Pencapaian hasil yang maksimal dari belajar siswa akan menentukan hasil belajar siswa tersebut.

Pembelajaran merupakan suatu proses penyampaian pengetahuan, yang dituangkan ke siswa dalam bentuk dalam pengetahuan (Oemar Hamalik, 2008: 25). Pembelajaran merupakan suatu proses atau rangkaian dalam upaya guru dapat membuat siswa belajar. Prose belajar diawali dengan penyusunan perangkat pembelajaran yang meliputi perencanaan program tahunan (prota), program semester (promes) dan penyusunan persiapan mengajar, persiapan perangkat pembelajaran berupa media, alat peraga ataupun 
evaluasinya (Hisyam Zaini, 2004: 4). Kesimpulan dari pendapat pendapat adalah pembelajaran merupakan suatu upaya guru dalam kaitannya dengan interaksi dengan siswa sehingga dapat membuat siswa belajar dengan baik, sekolah mempersiapkan pembelajaran dengan baik untuk masa sekarang, dan masa depan selain itu juga mempersiapkan siswa untuk hidup di tengah masyarakat. Salah satu mata pelajaran di SD yang memuat pengetahuan tentang alam sekitar adalah Ilmu Pengetahuan Alam. Mata pelajaran ini dapat membantu siswa memperoleh pengetahuan, wawasan yang diperoleh dari pengalaman melalui serangkaian proses ilmiah, siswa dapat menyelidiki, meyusun dan menyajikan data serta dapat mengungkkan gagasan atau ide ide yang dimiliknyaa

IPA berkaitan dengan suatu penyelidikan suatu alam secara tersusun, sehingga IPA tidak sekedar menguasai sebuah sistematis dan IPA juga tidak sekedar menguasai pengetahuan yang berupa fakta-fakta, konsep-konsep atau prinsip-prinsip saja, tetapi juga merupakan suatu proses penemuan (Sri Sulistyorini, 2007: 39). Menurut Iskandar IPA adalah IPA SD merupakan Ilmu mempelajari peristiwa-peristiwa yang terjadi alam (Iskandar, 2001: 2). Ilmu Pengetahuan Alam merupakan mata pelajaran di SD yang dimaksudkan agar siswa mempunyai pengetahuan, gagasan dan konsep yang terorganisasi tentang alam sekitar, yang diperoleh dari pengalaman melalui serangkaian proses ilmiah antara lain penyelidikan, penyusunan dan penyajian gagasan-gagasan. Pada prinsipnya, mempelajari IPA sebagai cara mencari tahu dan cara mengerjakan atau melakukan dan membantu siswa untuk memahami alam sekitar secara lebih mendalam (Depdiknas dalam Suyitno, 2002: 7).

Dari beberapa pendapat di atas maka dapat disimpulkan pembelajaran IPA adalah ilmu yang mempelajari peristiwa-peristiwa yang terjadi di alam dengan melakukan observasi, eksperimentasi, penyimpulan, penyusunan teori agar siswa mempunyai pengetahuan, gagasan dan konsep yang terorganisasi tentang alam sekitar, yang diperoleh dari pengalaman melalui serangkaian proses ilmiah antara lain penyelidikan, penyusunan dan penyajian gagasan-gagasan. Metode secara harfiah berarti "cara" yaitu suatu cara berdasarkan fakta dan konsep secara sistematis untuk melakukan suatu kegiatan yang dilakukan secara sistematis dan teruku (Muhibbin Syah, 2010: 198). Menurut (Sanjaya, 2006: 147) yang dimaksud dengan metode adalah suatu cara yang dalam rangka menerapkan sebuah rencana yang telah dibuat agar keinginan yang telah dibuat tersebut tercapai secara maksimal. Metode adalah suatu langkah langkah yang ditempuh guru dalam rangka memenuhi tujuan pembelajaran. Suatu cara yang diterapkan oleh seorang guru yang telah diisusun dalam bentuk kegiatan nyata dan praktis agar terjadi proses belajar pada diri siswa untuk mencapai tujuan pembelajaran dapat disebut dengan metode pembelajaran. Metode pembelajaran merupakan suatu cara yang telah diracik secara maksimal untuk menciptakan kualitas pembelajaran yang maksimal (Riyanto dalam Taniredja, 2012: 1).Berdasarkan pengertian di atas dapat disimpulkan bahwa suatu cara yang dilakukan untuk hasil yang optimal dengan cara menyajikan menguraikan, dan memberi latihan kepada siswa dapat dikatakan sebagai metode pembelajaran. Metode pembelajaran bukan saja berperan sebagai penyalur materi pembelajaran saja, tetapi juga berfungsi dalam interaksi kegiatan pembelajaran yang menciptakan hubungan searah ataupun dua arah, dan banyak arah sehingga siswa dapat belajar dengan baik dalam rangka memenuhi tujuan dari pembejaran tersebut secara tepat (Suwarto, 2017).

Metode pembelajaran Discovery Learning adalah metode pembelajaran yang berpusat pada siswa. Siswa dalam satu kelas dibuat dalam kelompok kelompok kecil dan kepada mereka di hadapkan padasuatupersoalanuntukmencarijawabanataspertanyaan- 
pertanyaan dalamsuatuprosedurdanstrukturkelompokyangdigariskansecarajelas. Menurut (Suryosubroto, 2009:178)Prosedur dalam metode dsicovery learning sebelum sampai tahap generalisasi antara lainpengajaran, perseorangan, manipulasi obyek dan percobaan. Komponen dari metode ini dapat membuat siswa berpikir lebih maju dalam belajar selain itu siswa dilatih untuk berorientasim mencari tahu sendiri sehingga belajar siswa menjadi lebih aktif, reflektif.

Menurut Hanafiah (2009:177) Metode pembelajaran Discovery Learning merupakansuatu rangkaian kegiatan pembelajaran yang melibatkan seluruh kemampuan siswa secara maksimal untuk mencari dan menyelidiki secara sistematis, kritis, danlogis, sehingga siswa dapat membangun sendiri pengetahuan, wawasan, sikap, dan keterampilan sebagai wujud dari hasil belajarnya.. Dari beberapa pendapat diatas metode Discovery Learning dapat diartikan sebagai perubahan perilaku siswa melalui penerapan proses pembelajaran yang ditentukan oleh mereka, dimulai dari menyelidiki, menganalisa, membuat eksperimen dan menyimpulkan suatu pengetahuan baru. Tujuan dari pembalajaan metode Discovery Learning yaitu: meningkatkan keterlibatan siswa secara langsung dalam mencari, megolah proses pembelajarannya. Memfokuskan para siswa agar selalu belajar sepanjang hayatnnya. Membantu siswa dagar tidak tergantung dengan gurunya. Selama ini siswa selalu tergantu dengan gurunya dan menganggap gurunya sebagai satu-satunya sumber informasi. Melatih para siswa menggali dan memanfaatkan lingkungannya sebagai tempat mencari informasi yang akan terus dicari oleh siswa.

Suryosubroto, (2009: 184) menyebutkan langkah langkah pelaksanaan Metode pembelajaran Discovery Learning antara lain: Mengidentifikasi kebutuhan kebutuhan siswa apa saja yang harus dipenuhi; menyeleksi prinsip yang digunakan, memahami konsep konsep yang akan diberikandan melakukan generalisasi yang akan dipelajari; menyeleksi materi dan masalah maupun tugas yang akan diberikan; menyiapkan penataan ruang kelas dan apa saja yang dibutuhkan di dalam kelas; siswa diberikan waktu dan kesempatan untuk melakukan penemuan; membantu siswa memperoleh data atau informasi yang tidak diketahui oleh siswa; merangsang proses hubungan antara siswa; menolong siswa mengeneralisisasi dan menyusun hasil penemuannya, jika dirasa perlu. Tahapan yang dilakukan dalam melaksanakan metode pembelajaran Discovery Learning (Hanafiah, 2009 : 80). Merumuskan topik permasalah yang akan diberikan dan dipecahkanolehsiswa; Membuat hipotesis atau dugaan sementara; Siswa dapat memperoleh informasi ataupun data yangdiperlukan untuk menjawabpermasalahan; Siswamenarikkesimpulanjawaban; Menyajikan hasil kesimpulan.

Menurut Suryosubroto, (2009 : 185) Kelebihan dari metode Discovery Learning ini yaitu metode ini membantu siswa menguasai keterampilan dalam proses kognitif sehingga siswa menjadi lebih berkembang; selain itu juga metode ini dapat membuat siswa menjadi bersemangat belajar bagi siswa; metode ini membuat siswa lebih maju dengan keampuannya sendiri karena metode ini memberi ruang atau kesempatan siswa dengan kemampuannya; siswa dapat belajar senidri bagaimana cara belajar yang baik, sehingga siswa merasa dilibatkan dan bersemanagat sendiri untuk belajar; metode ini dapat memperkuat mental siswa dan membangun kepercayaan diri siswa melalui proses penemuan; metode pembelajaran ini tidak berpusat pada guru melainkan pada siswa. 
Dalam metode ini guru berperan sebagi fasilitator, motivator dan pendamping siswa belajar, bila diperlukan. Sedangkan kekurangan metode pembelajaran Discovery Learning yaitu : Siswa harus memiliki kesiapan dan kematangan mental; Siswa harus berani dan berkeinginan untuk mengetahui keadaan sekitarnya dengan baik; Metode ini kurang berhasil digunakan dikelas kelas rendah; guru dan siswa yang sudah terbiasa dengan perencanaan dan pengajaran tradisional mungkin akan merasa bingung jika menggunakan metode Discovery Learning; metode ini hanya mementingkan proses pembentukkan sikap dan keterampilan tetatpi melupakan proses mental siswa; Penelitian telah dilakukan oleh Bambang Supriyanto (2016) Pada siswa kelas 4 SD Kutoharjo 01 Pati kabupaten Pati. Hasil penelitian dengan pendekatan discovery bagi anak dapat meningkatkan aktivitas dan hasil belajar serta mampu memberikan situasi belajar dikelas menjadi aktif, sehingga membangkitkan minat belajar siswa. Selain itu penelitian juga dilakukan oleh Gina Rosarina (2016) di SDN Gudang kopi I Berdasarkan hasil temuan dan pembahasan, dapat direkomendasikan bahwa dengan menerapkan model discovery learning merupakan suatu alternatif untuk meningkatan hasil belajar siswa, khususnya pada materi perubahan wujud benda.

Berdasarkan latar belakang masalah tersebut maka penulis tertarik untuk mengkaji lebih dalam tentang Peningkatan Hasil Belajar IPA Materi Konduktor dan Isolator Metode Discovery Learning Siswa Kelas VI SDN Cemani 03 Tahun Pelajaran 2018/2019". Adapun rumusan masalah dalam penelitian yang akan dilakukan adalah apakah metode discovery learning dapat meningkatkan hasil belajar IPA materi kondutor dan isolator siswa kelas VI SDN Cemani 03 Kecamatan Grogol Kabupaten Sukoharjo Semester 2 tahun pelajaran 2018/2019. Adapun tujuan diadakan penelitian ini adalah untuk meningkatkan hasil belajar IPA materi konduktor dan isolator siswa kelas VI SDN 03 Kecamatan Grogol Kabupaten Sukoharjo Semester 2 Tahun Pelajaran 2018/2019 melalui pembelajaran Discovery learning.

\section{Metode Penelitian}

Penelitian Pelaksanaan dilakukan di SDN Cemani 03 Kecamatan Grogol Kabupaten Sukoharjo pada siswa kelas VI semester 2 tahun pelajaran 2018/2019 Alasan pemilihan adalah karena penulisaktif mengajar di temapat tersebut, sehingga memudahkan dalam pelaksanaan tindakan. Penelitian akan dilakukan selama 5 bulan yaitu dari bulan Januari 2019 sampai Mei 2019. Kegiatan tersebut dibagi dalam tahapan yaitu tahap ijin penelitian, tahap pelaksanaan dan tahap penyusunan hasil penelitian tindakan kelas. Adapun hari dan tanggal pelaksanaan penelitian Siklus Iakan dilaksanakan sebanyak 2 kali pertemuan. Pertemuan pertama dilaksanakan pada da hari Rabu, 20 Februari 2019 dan pertemuan kedua hari Rabu, 27 Februari 2019, sedangkan siklus II juga akan dilaksanakan dua kali pertemuan yaitu pertemuan pertama hari Kamis, 21 Maret 2019 dan pertemuan kedua Kamis, 28 Maret 2019. Subjek penelitian adalah seluruh siswa kelas VI Sekolah SDN Cemani 03 Kecamatan Grogol Kabupaten Sukoharjo Semester 2 Tahun Pelajaran 2018/2019 yang berjumlah 37 siswa. Objek dalam penelitian merupakan proses pembelajaran IPA Materi Konduktor dan Isolator siswa kelas VI SDN Cemani 03 Kecamatan Grogol Kabupaten Sukoharjo melalui penggunaan metode pembelajaran discovery learning.

Data diperoleh dari guru dan siswa tentang pelaksanaan pembelajaran IPA konduktor dan isolator dengan metode Discovery Learning; Sumber data dalam penelitian 
ini diambil dari perolehan data hasil belajar IPA siswa; Data tentang pelaksanaan pembelajaran diperoleh dari dokumen berupa RPP yang telah menggunakan metode discovery learning, dan kurikulum yang disusun oleh guru dan dokumentasi foto dan hasil tes. Pada pelaksanaan dalam penelitian ini, tehnik pengumpulan data yang digunakan penulis meliputi tiga teknik, ketiga teknik tersebut diharapkan bisa dikolaborasikan sehingga mendapatkan hasil yang sesuai dengan apa yang diinginkan. Teknik pengumpulan data yang digunakan tersebut adalah dokumen, teknik tes dan teknik observasi. Instrumen yang dipakai dalam penelitian ini harus memiliki validitas yang handal. Validitas merupakan derajat ketepatan antara data yang terjadi pada obyek penelitian dengan daya yang dapat dilaporkan oleh peneliti. Teman sejawat digunakan sebagai validitas dalam penelitian ini, teman sejawat, merupakan teman satu sekolah yang nantinya membantu peneliti dalam menganalisis, mengoreksi, mengamati jalannya proses pembelajaran. Ketuntasan belajar mata pelajaran IPA di SDN Cemani 03 telah ditentukan berdasarkan Kurikulum 2013 yang telah dibuat sekolah, yaitu 70, siswa dinyatakan tuntas belajar bila telah mencapai hasi /nilai sesuai KKM atau Kriteria Ketuntasan Minimal.

Siswa akan diinyatakan tuntas belajar bila di kelas tersebut $80 \%$ telah mencapai KKM. Metode pembelajaran discovery learning akan dinyatakan mampu meningkatkan hasil belajar IPA materi konduktor dan isolator jika indikator keberhasilanpembelajaran telah tercapai. Indikator keberhasilan pembelajaran dengan Metode pembelajaran discovery learning meliputi: Perolehan hasil belajar IPA siswa kelas VI dinyatakan berhasil apabila prosentasiketuntasan belajar secara klasikal $\geq 80 \%$ (minimal $80 \%$ siswa memperoleh $\geq 70$ ) dan perolehan nilai rata-rata di kelas mencapai $\geq 70$.Penelitian Tindakan Kelas (PTK) ini direncanakan selama 2 siklus saja. Masing masing siklus akan dilakukan dalam dua kali pertemuan, di setiap pertemuan memerlukan waktu 70 menit atau 2 × 35 menit, jadi satu siklus akan memakan waktu 4 jam pelajaran untuk menyelesaikan proses pembelajaran .

Tahapan dari Penelitian Tindakan Kelas meliputi 4 tahap yaitu perencanaan, pelaksanaan, observasi dan refleksi. Tahap perencanaan, pada tahap perenacanan ini kegiatan yang dilakukan peneliti pada tahap perencanaan tindakan ini adalah menyusun Rencana Pelaksanaan Pembelajaran (RPP), setelah selesai tahap perencaanan, tahap berikutnya adalah pelaksanaan, pada tahap pelaksanaan ini siswa diberikan pembelajaran yang telah dibuat sesuai dengan perencanaan di awal dan telah menggunakan metode yang ingin diterapkan, tahap observasi atau tahap pengamatan dilakukan bersamaan dengan tahap pelaksanaan tindakan, hal ini dikarenakan hasil pengamatan diperoleh selama proses tindakan berlangsung.

Dalam pelaksanaan perbaikan pembelajaran, peneliti melakukan pengamatan terhadap aktifitas, aktifitas siswa ini dicatat memakai lembar observasi serta instrumen tes evaluasi di akhir setiap siklusnya yang telah dipersiapkan dalam tahap perencanaan. Hasil pengamatan yang diperoleh dijadikan dasar untuk melaksanakan perbaikan pada tindakan selanjutnya, tahap terakhir adalah tahap refleksi pada tahap ini peneliti melakukan analisis dan refleksi data yang terkumpul selama kegiatan pembelajaran. Setelah hasil tes dianalisis dan direfleksikan akan menentukan tindakan selanjutnya apakah akan berhenti atau melanjutkan ke siklus selanjutnya. 


\section{Hasil Penelitian}

Data refleksi kondisi awal dan tiap siklusnya membuktikan ternyata metode pembelajaran discovery learning banyak melibatkan siswa dalam belajar IPA Materi Konduktor dan Isolator, menjadikan siswa termotivasi dan merangsang siswa lebih aktif kembali dalam berdiskusi untuk mencapai pemahaman materi pembelajaran.Ketuntasan belajar siswa diketahui di kondisi awalnya hanya sebesar $62 \%$. Siklus 1 persentase ketuntasan $81 \%$ dan mengalami peningkatan pada siklus 2 menjadi $100 \%$. Pencapaian ketuntasan hasil belajar IPA Konduktor dan Isolator di setiap siklusnya dapat dilihat dalam tabel berikut.

Tabel 1. Pencapaian Ketuntasan

\begin{tabular}{lcccc}
\hline Tahapan Siklus & \multicolumn{2}{c}{ Ketuntasan Siswa } & \multicolumn{2}{c}{ Prosentase Ketuntasan } \\
& Tuntas & Belum Tuntas & Tuntas & Belum Tuntas \\
Kondisi Awal & 23 & 14 & $62 \%$ & $38 \%$ \\
Siklus I & 30 & 7 & $81 \%$ & $19 \%$ \\
Siklus II & 37 & 0 & $100 \%$ & $0 \%$ \\
\hline
\end{tabular}

Pada kondisi awal sebelum diadakannya penelitian ini diketahui hasil belajar IPA Materi Konduktor dan Isolator pada siswa kelas VI SDN Cemani 03, Kecamatan Grogol, Kabupaten Sukoharjo, Semester 2 ini, masih sangatlah rendah. Data dari prosentase ketuntasan belajar IPA baru mencapai $62 \%$ hal ini dikarenakan penyampaian materi oleh guru secara konvensional yaitu tanpa menggunakan metode pembelajaran. Perolehan nilai rata-rata ulangan harian sebelum diberikan metode ini ini hanya sebesar 68, dengan perolehan nilai terendah 40 , sedangkan perolehan nilai tertinggi hanya mencapai angka 80 , dari 37 siswa kelas VI hanya ada 14 siswa atau $38 \%$ yang masih belum mencapai nilai KKM di SDN Cemani 03, hanya 24 siswa atau 62\% siswa dari 37 siswa kelas VI mampu memenuhi nilai KKM.

Alternatif solusi atau pemecahan yang akan diberikan oleh guru dalam mengatasi rendahnya hasil belajar IPA materi konduktor dan Isolator siswa kelas VI tersebut adalah dengan menggunakan metode pembelajaran yang membuat siswa tertarik dan memotivasi siswa dan dapat membangun pengetahuan siswanya sendiri melalui gagasan gagasan atau ide ide yang diperoleh melalui penemuan. Metode yang dimaksud adalah pembelajaran discovery learning. Pelaksanaan kegiatan penelitian pada siklus I menunjukkan peningkatan dibandingkan dengan kondisi awal sebelum tindakan, terlihat penigkatan perolehan nilai rata rata hasil belajar siswa SDN Cemani 03, Kecamatan Grogol, Kabupaten Sukoharjo, Semester 2 Tahun Pelajaran 2018/2019 data hasil penelitian siklus I diketahui yaitu nilai rata-rata ulangan harian sebesar 79 , untuk nilai terendah diperoleh 60 , sedangkan perolehan nilai tertinggi mencapai nilai 90, sedangkan kehadiran siswa menacapai $100 \%$ atau 37 siswa kelas VI SDN Cemani 03 mengikuti pembelajaran di siklus I ini. Siswa mampu memenuhi ketuntasan pada kegiatan tindakan di siklus I terdapat $81 \%$ atau 30 siswa dari 37 jumlah siswa keseluruhan yang telah mencapai atau melampaui KKM yang telah ditetapkan sedangkan $19 \%$ atau 7 siswa dari 37 siswa belum mencapai atau masih di bawah KKM yang telah ditetpkan. 
Hasil belajar siswa setelah dilakukan tindakan di siklus I ini ternyata mengalami peningkatan yang cukup baik, meskipun telah mencapai indikator kinerja $80 \%$. penelitian harus dilanjutkan ke siklus selanjutnya yaitu siklus II untuk mendapatkan hasil optimal. Perbaikan-perbaikan kekurangan dari observasi kegiatan siklus I akan dilakukan pada pelaksanaan siklus II. Baik dari faktor seperti faktor guru maupun faktor siswa, terjadi peningkatan rata rata ulangan harian yang signifikan dan cukup tajam pada kegiatan siklus II yaitu diperoleh nilai ulangan rata-rata 85 , untuk nilai terendah diperoleh nilai80, sedangkan perolehan nilai tertinggi yaitu 100, dari keseluruhan siswa kelas VI sebanyak 37 siswa, 100\% siswa yang telah memenuhiatau melampaui nilai KKM atau $100 \%$ atau 37 siswa telah mencapai ketuntasan belajar. Tindakan kegiatan di siklus II ini diketahui persentase ketuntasan $100 \%$ sudah melampaui indikator kinerja yang telah ditentukan sebesar $80 \%$ sehingga peneliti tidak melanjutkan ke siklus selanjutnya dan menyudahi penelitian dan hanya sampai siklus II. Perolehan data peningkatan hasil belajar IPA Materi Konduktor dan Isolator dengan menggunakan metode pembelajaran discovery learning dapat dilihat pada tabel dibawah ini:

Tabel 2 Hasil Peningkatan Tiap Siklusnya

\begin{tabular}{llccc}
\hline No & Uraian & Kondisi Awal & Siklus I & Siklus II \\
1 & Nilai Tertinggi & 80 & 90 & 100 \\
2 & Nilai Terendah & 60 & 60 & 80 \\
3 & Nilai rata-rata & 62 & 79 & 85 \\
4 & Tuntas & 23 & 30 & 37 \\
5 & Tidak tuntas & 14 & 7 & 0 \\
\hline
\end{tabular}

Dengan demikian hipotesis tindakan penelitian tindakan kelas ini bahwa "Melalui metode discovery learning di duga dapat meningkatkan hasil belajar IPA materi konduktor dan isolator siswa kelas VI SDN Cemani 03 Kecamatan Grogol Kabupaten Sukoharjo semester 2 tahun pelajaran 2018/2019" terbukti kebenarannya"

\section{Pembahasan}

Hipotesis tindakan yang menyatakan bahwa melalui penerapan metode pembelajaran discovery learning dapat meningkatkan hasil belajar mata pelajaran IPA Materi Konduktor dan Isolator Siswa Kelas VISDNCemani 03 Kecamatan Grogol Kabupaten Sukoharjo Semester 2 Tahun Pelajaran 2018/2019 terbukti kebenarannya. Hasil penelitian yang telah dilakukan menunjukkanbahwa hasil belajar IPA Materi Konduktor dan Isolator yang diperoleh siswa sebelum diberikannya tindakan masih rendah, data diperoleh pada kondisi sebelum diberikan tindakan adalah nilai rata-rata hasil belajar sebesar 68, perolehan nilai rata rata tersebut belum memenuhi KKM yang telah ditetapkan, yaitu dengan KKM $>70$. Atas dasar hal tersebut, maka siswa Kelas VISDN Cemani 03, Kecamatan Grogol, Kabupaten Sukoharjo, Semester 2 Tahun Pelajaran 2018/2019 secara klasikal belum mencapai ketuntasan belajar, Karena dirasa belum tercapai ketuntasasn belajar maka peneliti memutuskan untuk memberikan tindakan dengan metode discovery learning. Setelah diberikan metode pembalajaran diperoleh peningkatan pada tindakan siklus I. 
Adapun hasil peningkatan pada siklus I ini berupa peningkatan nilai rata rata dan peningkatan nilai ketuntasan belajar. Nilai rata rata pada siklus I diperoleh sebesar 79 dari sebelum diberi tindakan 68 menjadi 79 terjadi peningkatan sebesar 10, ketuntasan belajar siklus I ini sebesar $81 \%$ telah mencapai ketuntasan klasikal yang diharapkan peneliti, meski telah mengalami peningkatan tetapi peneliti merasa belum puas sehingga peneliti memutuskan untuk melanjutkan penelitian ke siklus selanjutnya yaitu siklus II masih menggunakan metode yang sama, pada akhir kegiatan siklus II didapat nilai rata-rata hasil belajar IPA yaitu sebesar 85 . Ketuntasan belajar siswa pada siklus II meningkat menjadi sebesar $100 \%$, terjadi peningkatan dari sebelum tindakan sampai dengan siklus II, karena sudah maksimal maka peneliti memutuskan untuk berhenti di siklus ke II ini.

Sebelum tindakan ini penguasaan ketuntasan belajar IPA kleas VI SDN Cemani 03 Kecamatan Grogol Kabupaten Sukoharjo secara klasikal, baru mencapai 62\% dan jauh di bawah indikator ketuntasan kelas sebesar $\geq 80 \%$. Hasil belajar yang masih belum memuaskan diindikasikan disebabkan karena belum menggunakan metode pembelajaran yang dapat menarik siswa dan membuat siswa bersemangat. Hasil penelitan yang pernah dilakukan oleh Agus Supriyadi (2013) pada siswa kelas IV SDN 03 Sungai Ambawang Kubu Raya Ngawi juga menunjukkan adanya peningkatan hasil belajar melalui metode discovery learning. Peningkatan tersebut dikarenakan metode pembelajaran tersebut melibatkan siswa melalui penemuan sehingga membuat siswa tertarik mengikuti pembelajaran dan juga menyenangkan. Beberapa penelitian diatas membuktikan bahwa metode pembelajaran discovery learning dapat meningkatkan hasil belajar siswa.

\section{Simpulan dan Saran}

Berdasarkan data analisis dan pembahasan peneliti menarik kesimpulan bahwa: "Melalui pembelajaran discovery learning di duga dapat meningkatkan hasil belajar IPA materi konduktor dan isolator siswa kelas VI SDN Cemani 03 Kecamatan Grogol Kabupaten Sukoharjo semester 2 tahun pelajaran 2018/2019" terbukti kebenarannya" Peningkatan nilai rata-rata IPA siswa, yaitu dari 68 sebelum diberi tindakan, setelah diberikan tindakan siklus I meningkat menjadi 79dan meningkat kembali menjadi 85 setelah tindakan di siklus II. Sedangkan peningkatan ketuntasan belajar siswadari $62 \%$ pada kondisi awal meningkat menjadi $81 \%$ pada siklus I dan meningkat menjadi $100 \%$ pada siklus II.

Selain peningkatan nilai rata-rata IPA dan ketuntasan belajar IPA, Peningkatan kriteria ketuntasan secara klasikal jugasudah tercapai, yaitu mencapai tingkat ketuntasan kelas sebesar $100 \%$ atau $\leq$ KKM sebesar $70 \%$. Sehingga tidak perlu dilakukan tindakan siklus.Saran yang dapat peneliti sampaikan setelah melaksanakan perbaikan pembelajaran yaitusebaiknya guru menggunakan metode metode mengajar yang tepatsesuai karakteristik siswa dan materu yang akan diajarkan sehingga akan diperoeh hasil yang diharapkan; Metode yang digunakan merupakanmetode pembelajaran yang berpusat pada siswa, bukan berpusat pada guru, sehingga memotivasi siswa dan membuat siswa lebih bersemangat dalam mengikuti proses kegiatan pembelajaran.

\section{Daftar Rujukan}


Baharuddin dan Wahyuni, N, (2007). Teori Belajar dan Pembelajaran. Yogjakarta: ArRuzz Media Group.

Dimyati dan Mujiono. (2006). Belajar dan Pembelajaran. Jakarta: Rineka Cipta.

Hanafiah Nanang dan cucu Suhada. (2009). Konsep Strategi Pembelajaran. Bandung : Refika Adhitama.

Hisyam, Zaini dkk. (2004). Strategi Pembelajaran Aktif. Yogyakarta: CTSD

Iskandar.(2001). Pendidikan IPA. Bandung: Maulana.

Jogiyanto. (2006). Pembelajaran Metode Kasus. Yogyakarta : CV Andi Offset.

Kamus Besar Bahasa Indonesia, Edisi Keempat. (2008). Jakarta: Gramedia Pustaka.

Muhibbin Syah. (2000). Psikologi Pendidikan, Bandung: Remaja Rosda Karya.

Oemar Hamalik. (2008).Kurikulum dan Pembelajaran. Jakarta: Bumi Aksara.

Sri Sulistyorini. (2007). Pembelajaran IPA Sekolah Dasar. Semarang: Tiara Wacana

Suyitno. (2002). Prosedur Penelitian Tindakan Kelas. Bogor: Ghalia.

Sanjaya, W. (2006). Strategi Pembelajaran. Jakarta: Kencana Prenada Media Group.

Suprapti Hariyani. (2019). Peningkatan Aktivitas dan Hasil Belajar IPA Materi Sistem Ekskresi Manusia melalui Model Pembelajaran Discovery Learning dan Metode Eksperimen Siswa Kelas VIII G SMP Negeri 1 Boyolali pada Semester Genap Tahun Pelajaran 2018-2019. Jurnal Pendidikan, volume 28(3), hal: 339-352.

Suwarto, S. (2009). Pengembangan tes dan analisis hasil tes yang terintegrasi dalam program komputer. Jurnal Penelitian dan Evaluasi Pendidikan, 13(1), 40-56.

Suwarto, S. (2017). Pengembangan tes ilmu pengetahuan alam terkomputerisasi. Jurnal Penelitian dan Evaluasi Pendidikan, 21(2), 153-161.

SuryosubrotoB. (2009). ProsesBelajarMengajardiSekolah. Jakarta: Rineka Cipta Taniredja,Tukiran dkk. (2012).Model-model Pembelajaran Inovatif. Bandung: Alfabeta Undang-undang No. 20 Tahun 2003 Tentang Sistem Pendidikan Nasional. 